\title{
Molly Mason Remey: \\ "My Heart Is Set on my Children" \\ Part II: Mother and Navy Wife
}

H. H. Wubben*

When the Civil War ended, tWenty-year-old Molly Mason was a young woman upon whom the world smiled. Molly was the daughter of Burlington, Iowa's Charles Mason, a prosperous landowner, patent lawyer, businessman, nationally known Democrat and wartime Copperhead. Well educated for her time, musically talented, socially successful and religiously fulfilled, there was no reason for her to anticipate that life would deal harshly with her. Fortunately, for the most part, it did not, since she was to live nearly seventy-three more years. Neither feminist nor doormat, Molly Mason Remey experienced minor triumph and tragedy. She achieved some important personal goals. Those which evaded her evoked quiet regret, not mordant self pity. ${ }^{1}$

During the late 1860 s and early 1870 s she and her mother lived much of the time in Burlington while Charles Mason practiced patent law in Washington, D.C. If society in the river city was less formal than in the nation's capital, it still was not dull. Enlivening the 1867 summer was a round of

*The author wishes to thank Mrs. Julia Ward Stickley and Miss Molly Hains of Washington, D.C. for information which helped him clarify his perspective on the Remey family history.

'Reconstruction of the final seventy-one years of Molly Mason Remey's life is not quite so simple a task as the first twenty-two since she ceased to keep a diary in 1867. [See: "Molly Mason: Nearly Everybody's Darling. Part I: The Civil War Era" in the Annals of Iowa, Vol. 43, No. 8 (Spring, 1977), 593-614] The main sources of information for part two of this article are volumes 7-12 of Charles Mason Remey, ed., "Life and Letters of Mary Josephine Remey... 1845-1938," twelve typescript vols. Also used were Remey, ed., "Life and Letters of Charles Mason . . . 1804-1882," twelve typescript vols., and Remey, ed., "Life and Letters of Rear Admiral George Collier Remey . . 1841-1928," six typescript vols. Hereafter the three different sets will be identified by the initials of the subject, namely, MJR, CM, and GCR. Volume numbers are omitted because the pages in vols. 7-12 of MJR, the only volumes of the MJR series used in this article, run consecutively, one through 976. CM and GCR pages are numbered consecutively without a break throughout both sets. 
parties which often featured one or another of three Remey brothers, George, William, or Edward-navy officers allsons of another leading Burlington family. Winter seasons were almost equally filled with more parties and masquerade dances. Molly rented a piano, but displayed her musical talent less and less, once by choice when she declined to sing at a charity concert for the poor (she offered no explanation). Intellectually she remained alive. She attended one of Bronson Alcott's "Conversations" at a Burlington home where he enlightened the audience on the subject, "Culture." Revealing one of her occasional flashes of irony she wrote: ". . . . a good many of his remarks were very sensible, and many rather abstruse. His style was somewhat oracular, and as he is a person of venerable appearance no one ventured to dispute his assertions." ${ }_{2}$

During those years several of her friends joined the ranks of the young marrieds. But the very attractive Molly did not quickly leap into matrimony. It was not until 1868 that she and twenty-eight-year-old George Remey decided to marry. The couple became engaged in September, 1871, and was married on July 8,1873 in Burlington. The joy of the wedding was dimmed a little by the deaths a few months earlier of the elder Mrs. Mason and the elder Mrs. Remey.

George Remey was always solicitous of his wife's well being, and he freely expressed his love for her when they were apart, which was often in the first two decades of their marriage. Anxiously awaiting the birth of their first child he counseled her,

Take good care of yourself; beware of the sewing machine. Remember what I have said about discipline. Make your kind friends wait on you. I wish I could be with you, for I know that I would make the best of slaves to you. And, I am not ashamed to confess that the sight of anything pertaining to yourself, even by association, causes a feeling of happiness to me. This sensation is just as tangible as any feeling. I am sure you will understand what I mean. I like to speak of it as it is evidence of mind, and how very much I am in love with my dearest girl. ${ }^{3}$

When the baby, a boy christened Charles Mason Remey, 
arrived, George confessed, "The truth is, I do not know much of the habits of a young gentleman of his age." When Molly wrote that the baby cried a lot, he counseled, "Of course the baby cries. You must not allow that to worry you. Why, he would not be a baby if he did not do so. At least such is my idea." He also forwarded warning from a doctor friend: "I told him I had a son. The first thing he said [was] 'Don't let your wife get up for month." " And a few days later: "Captain Walker insists that a woman ought to keep her bed for six weeks varied as you do by sitting up or lying on a lounge." Soon after, the Commander took a month's leave to visit wife and child in Burlington. The visit was entirely satisfactory, and upon his return to the East he described to Molly his feelings:

There is no doubt that people can be in love and attend business but the one so pervades one's thoughts and actions that it requires a strong effort to prevent its overshadowing our ordinary occupations, not that I believe its tendency is to injure business interests. For on the contrary I am satisfied that it is elevating in every sense of the word. You must not think I am philosophizing. ${ }^{4}$

These words accurately reflect George Remey's life-long affection for his wife. He did not always look forward to sea duty because of the separation it entailed. On taking command of the "Enterprise," a new sloop-of-war he said: "I don't know if I have described the Enterprise to you. My present description would be that a ship is a ship, a vessel that is sometimes sent to sea to separate a Naval Officer and his family to the unhappiness of both if they love each other as they should." ${ }^{5} \mathrm{He}$ did consult her when he had a choice of duty. They once decided, for example, that he should accept a staff position on the navy's European station because he knew this cruise would last no longer than a year and a half. Most such cruises lasted only that amount of time, but with bad luck he could draw a longer one. ${ }^{6}$

During George's many absences in those early years Molly had her hands full caring for the children that were born with

${ }^{4}$ GCR to MJR, May 31, June 9, 11, 14 and August 9, 1874, 105, 113-116 and 123, MJR. ${ }^{5}$ GCR to MJR, March 26, 1877, 161, MJR.

${ }^{6}$ GCR to MJR, August 25, 1881, 184, MJR. 
regularity. Charles Mason Remey was born May 18, 1874. George Remey, named after his father, arrived on Oct. 19, 1876. Angelica, always known as "Jecky," came on Sept. 3, 1879, Willie on Oct. 23, 1881, Mary on April 18, 1884, and John on July 9, 1890.

Tragedy struck twice during this time. Young George died of croup at the age of four on December 18, 1880. Then Molly's father, Charles Mason, died February 25, 1882. While he lived, Mason was very attached to his only surviving child. He took her marriage and his wife's death very hard and wrote sadly on the wedding day, "This forms another of the radical shocks of my life." 'Mason's gloom diminished somewhat during the course of a lengthy honeymoon tour of Europe which Molly and George persuaded him to take with them. Certainly for the rest of his life he had little room for complaint so far as his daughter's behavior was concerned. Molly lived with him much of the time when he was in Burlington, even when George Remey was stationed on the East Coast. The young Remeys named their first child after him and allowed him to develop an unusually close relationship with his namesake. They drew the line, however, when he begged them to let him adopt the boy. ${ }^{8}$

During his last illness Molly was with him in Burlington. George was on a cruise, and she had the care of three children, one of whom was less than six months old. The strain was great. In a letter to a friend she tells of the restrictions this placed upon her.

After my husband went to sea, there seemed to be no one but myself to attend to the numberless little duties required by an invalid ... I was always at hand to assist, my father steadily refusing the services of a servant. It was only during the last few days of his life that he was willing to avail himself of the help of a professional nurse.

Her husband was not due back in the states for a year: "I am trying to take care of the children until he comes, but sometimes I lose courage, for I am alone with them, except [for] the assistance of rather indifferent servants."

In the 1890s and early 1900s Molly Remey's life and hopes

'Diary, July 8, 1873, 1297, CM.

'Commentary, 178, MJR. 
are more clearly revealed than at any time since the Civil War. This is the period during which her much loved eldest son Mason left home to go to school. Mason may have been her favorite as he had been his grandfather's. Her letters to him from his prep school days at Ithaca, through three years of college at Cornell and several years of study at the Ecole des Beaux Arts display more than motherly affection-and there was plenty of that. She wanted him to be a success. Accordingly she praised, encouraged, warned, lectured, advised, cajoled, reprimanded (lightly) - and sent money. He rewarded her with regular letters and progress in his work. The letters also reveal how Molly subordinated herself to the needs of her children and to her husband's career. Her joys came largely from their successes. Thus, there is relatively little news of activities she engaged in for her own satisfaction. She almost never mentioned singing or playing the piano, activities which had filled many hours during her girlhood. Obviously she was not the voracious reader she had been. She once told young Mason she had time only to get through a weekly pictorial paper, the magazines and the newspapers in a week's time. Another time she wrote, "I do not read many books now-adays, but occasionally give myself a treat." "She sometimes went to the theater, to concerts or to lectures. A Christmas benefit show in Portsmouth, New Hampshire, entitled "Carnival of the Republic," provoked a comment to Mason:

You would have been astonished at their skirt dancing and high kicking. How mothers can see their daughters perform so in public passes my comprehension ... There was a drill of the young girls in costumes of the National colors, such a display of figures and limbs was startling ... The whole thing was monotonous and wearisome. ${ }^{10}$

There were over the years numerous social affairs which she attended or promoted in her role as wife of a successful navy officer. These, however, she viewed more as obligations than as occasions which were intrinsically enjoyable. Family life was more important. And the success of her children came first. One of many similar passages in her letters to Mason

'MJR to CMR, Feb. 26, 1893, and Feb. 21, 1896, 252 and 473-474, MJR.

${ }^{10} \mathrm{MJR}$ to CMR, Dec. 24, 1896, and Dec. 16, 1897, 565 and 645; MJR to CMR, May 5, 1896, 508, MJR. 
shows this. When he was at prep school she wrote earnestly, "The welfare of my children is my dearest earthly object, and to see them good and happy, my greatest ambition. Remember this in your work. While you are benefiting yourself, you are also doing me the greatest service." 11

Molly Remey's reports to Mason reveal that the children who remained at home were not peas in a pod and that each posed different kinds of trials for her. Jecky, her daughter, was not inclined to follow through on assigned tasks, and Molly sometimes had to finish up after her. She tended to keep a messy room, but when it was cleaned by a servant, Jecky insisted that all the "bric-a-brac . . . every card and ornament," be put back exactly as it was. ${ }^{12}$

Jecky was not enthralled by school, nor does it appear that her mother expected as much out of her as the others. When she was fourteen, Molly noted drily, "Jecky has commenced the study of insects, etc. She is trying to draw a grasshopper from a specimen that has been drowned, but has not succeeded." Molly was not unsympathetic towards her, however. When the family moved to Washington in the fall of 1895 , she got Jecky into a private school. She entered "in trepidation" but tried to be brave at the same time, Molly wrote Mason. Eventually, back in Portsmouth, Molly quit trying to get her oldest daughter, then a few months past seventeen, to master algebra. Still, she pressed Jecky to overcome deficiencies in physiology and physics. Jecky had more interest, however, in history and literature, though one surmises that it was not a compelling interest. ${ }^{13}$

In the summer of 1898 Mason suggested that Jecky might like to join him and Willie who was with him in Paris. Molly reported that although the adventurous Mary who was too young would jump at the chance, Jecky didn't wish to leave home. Finally in the fall of 1900 she did go. Her mother warned Mason that he would have to manage her financial affairs; Jecky, she said, was frugal with her own money, but always managed to spend her mother's freely. When Jecky returned

"MJR to CMR, Oct. 10, 1894, 336, MJR.

${ }^{12}$ MJR to CMR, Aug. 23, 1892, April 18, 1894, and May 2, 1895, 222, 311 and 395, MJR.

${ }^{13}$ MJR to CMR, Oct. 3, 1894, Oct. 4 and 7, 1895, and Jan. 10, 1897, 333, 414, 416 and 574, MJR. 
home a year later, Molly noted with surprise that there was a change: "Jecky had no trouble whatever in landing and passing the Customs officials; in fact I think she shows more selfreliance in traveling than in anything else." ${ }^{14}$

Mary was different. At the age of nine she demonstrated so much aptitude with a drum that the family got her a violin (although no one bothered to explain the connection). In school she was an excellent student. At the age of thirteen she became so enamored of photography that she began to sew for her mother to earn money for film. Mary was not bashful about seeking out subjects, to her mother's dismay. One was Admiral Pascual Cervera, a prisoner from the war with Spain who was held at the Portsmouth naval yard for a short time in the summer and fall of 1898. The Admiral didn't mind at all, and Mary was delighted. "He is not a bit like a Spaniard, he looks like a good old farmer," she gaily wrote her older brother, a comparison which might have amused the elderly admiral. In 1899, Mary developed another passion, basketball. Her mother didn't know quite what to think of it. "It can be played moderately," she informed Mason, "but is apt to become rough." And, as her mother expected, she pestered her parents to allow her to go to Paris in the summer of 1900 to live with her older brother for awhile. She was not successful. But on smaller matters she won. When William Jennings Bryan came to Portsmouth to speak in early 1900, Molly declared it "absurd" that school children should be let out to hear him. She "remonstrated" with Mary, "but she was so bent on going that I yielded the point." 15

Mary was a driver. Over the years at public school and at a boarding school for girls she took French, English, chemistry, Virgil, Bible, drawing, art history, algebra, geometry, horseback riding, Latin, and what she called "important studies," history, physiology, astronomy, geology, physics, and music. She also continued with her violin lessons. Latin ultimately be-

${ }^{14}$ MJR to CMR, June 16,1898 , Oct. 22,1900 , and Nov. $24,1901,717,861$ and 921 , MJR.

${ }^{15}$ MJR to CMR, Dec. 3 and 5, 1893, and Oct. 31, 1895, 290, 292 and 428-429; MJR to CMR, Feb. 24, 1898, 670. MJR to WBR, Aug. 14, 1898, 763; Mary Remey to WBR, Sept. 21, 1898, 750-751, Dec. 17 and 21, 1899, and Jan. 7, 1900, 831, 833 and 840. Mary Remey to CMR, Jan. 21, 1900, 848. MJR to CMR, Feb. 1, 1900, 847, MJR. 
came a bore, and she enlisted the help of her older brother in getting out of it. There were subjects "more to my taste and turn of mind," she explained, "which I am far behind in or know nothing about ... You see there is plenty to do besides wasting my time and temper on stupid Latin which I hate. It even makes me cross to think of it." She won, partly it appears, because her mother agreed with her. ${ }^{16}$ Mary did toe the line on one important matter, so far as her parents were concerned. She was confirmed in the Episcopal Church during the winter of $1902 .{ }^{17}$

Willie for many years in the Remey letters comes through as a bright, studious boy without Mary's exuberance. He displayed a keen interest in working with wood. For getting good marks in school his parents once gave him a lathe. He liked getting tools and books for presents, or the money to buy them. By the age of fifteen he had added electricity and chemistry to his interests. Wherever they lived, part of the Remey's basement usually became Willie's workshop. He was also more help around the house than his sisters. When the family lost a housemaid to the temptation of Boston, his mother told Mason. "Willie is always ready to save me trouble." Mary and Jecky, she implied, were not; in fact, they "should learn to do more for themselves." 18

In 1898 the Remeys decided Willie needed a change. They sent him to Paris to live with Mason. Why he went is not clear, but it became apparent around the turn of the century that Willie was at least vaguely dissatisfied with life. His health was a worry, and he needed an occupation. His mother wrote Mason that the efforts of their Episcopalian minister to get him to join a confirmation class came to naught. He was, she said, "distressed," claimed he was not ready, and didn't want to be "importuned." He wasn't ready yet two years later either. Mary wanted to be confirmed, but she delayed, waiting in vain for Willie. "He is disposed to defer the duty," his mother wrote with some irritation, "but I hope he may see it differ-

${ }^{16}$ Mary Remey to CMR, Oct. 4, 1900, April 26, July 15, Nov. 18, and Dec. 11, 1901, 859, 883, 903-904, 918-919 and 923-925; Mary Remey to CMR, July 15, 1901, 903-904, MJR.

${ }^{1}$ Mary Remey to CMR, Feb. 10, 1901, 872-873. MJR to CMR, Mar. 16, 1902, 942, MJR.

${ }^{18}$ MJR to CMR, Oct. 29, 1893, Oct. 21 and Nov. 8, 1895, Dec. 20, 1896, Dec. 14 and 24 , $1899,282,423,431,562,829$ and 835 , Nov. $19,1899,823-824$. 
ently before the date arrives ... (Willie wasn't alone in his reluctance; Jecky was a holdout too). His trip to France came soon after, during the Spanish-American war. Molly was anxious. She cautioned both boys to engage in no arguments with Europeans about the war. And she instructed Mason to keep Willie from getting homesick. Willie was also to take some classes, one of which should be drawing. Otherwise Mason was to let him take anything else he fancied. He remained with Mason until some time in 1899. At least once their second son surprised the Remeys, that when Mason wrote that his brother had taken a girl to a ball and had, in the bargain, worn a stove pipe hat. ${ }^{19}$

Two years later, back again, twenty-year-old Willie still had not found himself. His worried mother worked to get him a "beneficial and interesting" job with a western expedition of a U.S. Geological survey crew. It might also be good for his health, she hoped. When this prospect fell through, the Remeys sent him on a pleasure trip to Colorado. A change of scenery might settle his mind, his mother hoped. In Colorado Springs, Willie lived briefly in a boarding house, then moved in with the family of a "street preacher." Although he only remained there for a few weeks, the stay ultimately did prove beneficial according to Willie. When he arrived in Colorado, he explained to Mason, he was confused about religion. Now, as a result of living with the door-to-door evangelist, his confusion was dispelled. Willie's host claimed that denominationalism was "unscriptural," that his task was simply to convert individuals to Christianity. "I now believe," wrote Willie to his brother, "that I have a hold of the Truth." 20

When he returned East later that summer, Will, as his family now called him, was not yet completely settled in his mind. At least Molly still worried. He was not inclined to return to school. Hopefully he would find some "Mechanical employment" that would "divert him." He did take up woodworking again and made toys for eleven-year-old John which, she noted, gave him some needed "exercise and diversion."

${ }^{19}$ MJR to CMR, Feb. 17 and Mar. 13, 1898, and Feb. 4, 1900, 667, 674 and 848, April 17, May 22 and 26, June 16, 1898, and Jan. 1, 1899, 688, 703-704, 708, 717 and 769, MJR.

${ }^{20}$ MJR to CMR, Feb. 8, Mar. 20, and April 12 and 19, 1901, 871, 876 and 879-881; Willie Remey, to CMR, May 28 and July 21, 1901, 891-892 and 904, MJR. 
Apparently her second son's health remained a problem for several years more despite osteopathic treatments for curvature of the spine which was thought to be the cause of his troubles. ${ }^{21}$

John Remey was a latecomer to the household, six years younger than Mary, born when his mother was forty-five years old. He lacked no attention and was obviously a family pet. He received many toys. But so had his brothers and sisters. The Remeys, despite Molly's occasional complaints about excess spending, were always in comfortable circumstances. When he was five, his mother was fifty, and his activity tired her to the point that she needed relief. When he was eight, his father proposed sending him to Farragut, a private military academy. Molly rejected this, though she didn't want him at a private school either. John's education, just like his sisters' and brothers,' was acquired at both private and public schools. ${ }^{22}$

If Molly Remey's life revolved about her children primarily, she was still a good navy wife. George Remey's career was important to her. But there were problems. By the mid-1890s, he and she were disturbed at rumors that younger career officers were working behind the backs of older men to win advancement. Certain other aspects of navy life bothered her also. When stationed at Washington in the winter of 1895 , she complained about the rigors of the social season. Some teas and receptions she avoided. Those she attended gave her no satisfaction. Finally she wrote Mason in exasperation, "I hope my formal duty calls are ended for the season, for they are stupid enough." ${ }^{23}$

Later that spring Captain Remey was assigned for a second time to command of the Portsmouth naval yard. Professionally it was a dull place so far as he was concerned, but the only other opening was the command of the Puget Sound station which, Molly declared, "cannot be thought of." Dull or not, Portsmouth had one advantage, she noted: command there

${ }^{21}$ MJR to CMR, Sept. 24, 1901, 913, Nov. 8, 1901, 917, MJR.

${ }^{22}$ MJR to CMR, Oct. 26, 1895, June 16, 1896, and Oct. 9, 1898, 424-425, 530 and 754, MJR.

${ }^{23}$ MJR to CMR, Nov. 29, 1895 and Feb. 11, 1896, 437-438 and 466-467, MJR. 
entailed less risk of failure than at a post where he'd had no experience. Soon, however, Molly was fretting that he might get sea duty again. "I don't know how I should manage with him and you away," she wrote Mason. ${ }^{24}$

Then in early 1898 the possibility of war with Spain worried her even more. By now she had long been comfortably reestablished at Portsmouth. Should war come she was certain that her husband would have to go to sea because of his experience, ability, and his long period of shore duty. Molly was skeptical about the war fever sweeping the country. Even though the general feeling as she read it was that Spain had nothing to do with sinking the "Maine," the newspapers kept up the agitation. "[T]hose who make the excitement do not expect to fight," she wrote Mason angrily. Yet when war talk got even more ominous, she experienced mixed feelings. She didn't want Captain Remey endangered. But she didn't want him to miss out on the professional opportunity war might afford. When Mason wrote asking why his father was not mentioned among those involved in the "war movements" she replied that it was because he was in Portsmouth. Those in prominent posts or those who had influence in Washington were getting the publicity. But she assured him, "If actual war comes, many who are talked about now will drop out and there is no danger but that your father will be given his share of fighting duty." 25

She was wrong. The navy assigned Captain Remey to command of the naval supply base at Key West, a noncombat post. His stay lasted little longer than the war, and he resumed command at Portsmouth by the end of August. Two worries ensued. Portsmouth, as a Spanish prisoner-of-war detention center, now hosted a battalion of Marine guards. Marine privates, she wrote her son, were not always "orderly or agreeable" and caused the yard commander many problems. Still, this was a minor inconvenience, and it evaporated soon with the departure of both the Spaniards and the Marines. The other lingered and caused some bitterness. Wartime promotions to rear admiral of William Sampson and Winfield

${ }^{25}$ MJR to CMR, Mar. 3, 10 and 13, and April 21, 1898, 672-675 and 689, MJR. 
Schley, victorious commanders at the Battle of Santiago, caused disappointment to the Remeys since both men had less time in grade than the Captain. For several months thereafter Molly's letters to Mason described the maneuvering in the Navy department and in congress to rectify the slight felt not only by Remey but also by a small host of other aggrieved captains who happened to be in the wrong place at the wrong time. Eventually Remey got his promotion to rear admiral, and, equally important, got his name placed ahead of Schley and Sampson on the promotion list. Even so Molly was not quite satisfied and complained that had the war not occurred, her husband's promotion would have come earlier by orderly succession in November, 1898. She also wrote Will, then in Paris, that so many captains made rear admiral that the title was cheap. She failed to sense that her husband was quite satisfied with his promotion. This comes through in a comment to Mason. She would, she wrote, probably have a party on the coming weekend, although she wasn't enthusiastic about the prospect as was Admiral Remey. A delayed promotion was still a promotion, and obviously a cause for celebration so far as the new admiral was concerned. ${ }^{26}$

One more important tour of duty now lay ahead. In early 1900 Admiral Remey became commander of the U.S. fleet in Asia. Molly noted that he was pleased at this chance to serve in the navy's "most important station." Remey held the post for nearly two years concurrent with the Phillippine Insurrection and the Boxer Rebellion. Molly and the children visited Mason in Paris for a few weeks after his departure. When she returned, she was not happy. Neither was the admiral. By this time fifty-eight years old, he missed his wife. He suggested that she come to Yokohama to be closer to him. However, she chose to live in Washington. As George Remey's duty extended into the middle of the year 1901, she began to grow impatient. She felt "desperately lonely." Living with Will and John was not easy. "We need your father so much each day . . . the interests

\footnotetext{
${ }^{26}$ MJR to CMR, Sept. 8, 11 and $15,1898,744,746-747$, Oct. 30 and Dec. $28,1898,756$ and 838; Mar. 5 and 26 and April 23, 1899, 782, 789 and 797; MJR to Willie Remey, April 20, 1899, 796, MJR. Sampson's and Schley's original promotions were temporary; their permanent promotion date was the same as Remey's, Mar. 3, 1899.
} 
of the family seem sacrificed to his public duty," she complained to Mason. When the war in the Phillippines was nearly over, she began to hope that he would feel that he'd spent enough time in the Far East. She seemed to assume that the admiral could depart at a time of his own choosing. " [C]ertainly," she opined, "he has all the glory that he is likely to get and the difference of a few months means a great deal to me." In the winter of 1902, Admiral Remey finally did come home. And on August 10, 1903, he retired at the age of sixty-two, having served forty-eight years minus six weeks in the navy. (He entered the naval academy when he was fourteen years old). ${ }^{27}$

Thereafter Molly and her husband lived primarily in Washington. The Iowa connection had become steadily eroded over the years. George wrote his wife in 1878 that Burlington didn't appeal to him much anymore. People there, he told her, were "too interested in everybody else's affairs." Members of the family went back for infrequent visits. Molly did hold onto the Mason home for many years, but only, as she told Mason, "for the sake of past associations." Burlington, she said (this in November, 1899), had few growth prospects, and the same money invested elsewhere would probably bring a better return. After Admiral Remey's retirement he sat for a portrait for the Burlington library. She did also, but, she said, not for the library, but for a "legacy for her children."

Retirement brought Molly Remey something she had long desired, a permanent home. The admiral got what he wanted too, location in Washington, although they spent most of their summers in Newport, Rhode Island. Mason Remey completed his architectural studies in Paris in 1903 and returned to the United States, thus bringing to an end the correspondence which so effectively revealed his mother's life throughout her middle years. Fortunately, he wrote a "Compiler's AfterWord" in the 1930s and preserved some other correspondence which tells something of her later years. ${ }^{28}$

As her children grew up and left home she became

${ }^{27}$ MJR to CMR, Mar. 4 and Oct. 22, 1900, 852 and 861, April 12 and July 22, 1901, 880 and 905, MJR.

${ }^{28}$ Conclusion of Vol. 12, following page 971, MJR. 
Molly Mason Remey

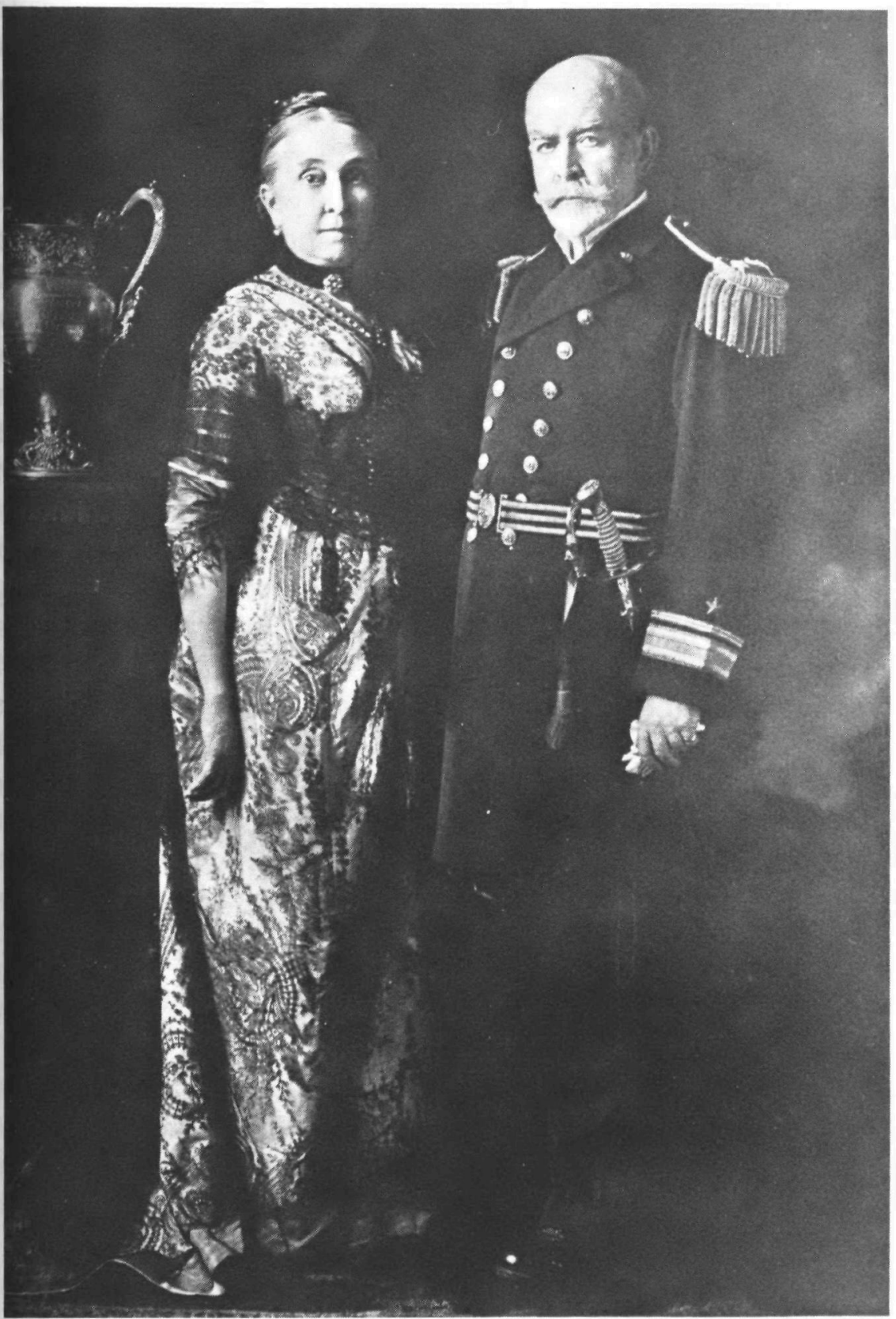

Portrait by Louis Szanto in the Historical Museum. Des Moines

Molly and George Remey in 1907 
involved in charitable work. She sewed and knitted clothes for the poor. She also took orders for knitting, contributing the income to the missionary activities of her church. During World War I she was active in the Red Cross for which she won a meritorious service medal. In 1922 overwork caused a mental and physical breakdown. Two years of constant care enabled her to recover mentally, but she remained a physical invalid until her death. Fortunately she never lacked for excellent professional care, pleasant physical surroundings and the attention of her family.

In 1925 Remey established in her name a foundation for the poor of the Episcopalian diocese of Washington, the funds to be administered without regard to race, creed or nationality. At her death in 1938 at the age of ninety-two, Mason Remey arranged for a small but elaborate funeral attended by close friends and relatives. Originally buried in the Washington, D.C. area, she now lies in the Mason family plot at Pompey, New York. ${ }^{29}$

One would like to know what Molly Remey thought of her long life in those last years. On her fiftieth birthday she wrote resignedly, "I tell the children that their existence reconciles me to growing old." This was consistent with an oft-expressed theme that she only desired her children's happiness and success. In a poignant letter to Mason four years later, she explained:

. . . it means a great deal to me to have you do well, for my heart is set on my children, and I hope to have them realize some of the things I have failed to accomplish. When I had youth and enthusiasm, many aspirations filled my mind which want of opportunity caused to perish, and thus I have settled into a commonplace sort of elderly woman. But I appreciate the feeling that a person has with life before them and I hope to give my children opportunities they desire. Just now your sisters are turning their attention to music, and it brings back to me many latent associations ... ${ }^{30}$

Was Molly Remey's married life through 1899 as frustrating as this suggests? Did she have much to complain about?

29 "Rear Admiral George Collier Remey, 1841-1928," Annals of Iowa, 3rd Ser., Vol. 19 (Oct., 1934), 404-405.

${ }^{30}$ MJR to CMR, April 12, 1895, 389, Aug. 16, 1899, 793-794. 
Clearly hers was a life most American women of the day could have envied. Her husband was a successful and rising naval officer. As an officer's wife, and as the only daughter of a wealthy man, she never truly lacked material comforts. She always had servants and a cook. Child care and housework, thus, were hardly the physical or mental burdens to her that they were to many women. Nor did she express much, if any, status anxiety throughout this period, at least about her own person; she was not ill at ease in the secure, ordered, comfortable society in which she moved, and she seems not to have yearned to belong to "high society" as it then existed at the turn of the century. She was not, of course, liberated from the necessity of being "proper;" neither was George Remey for that matter. Nor should one get the impression that life with George required endless self sacrifice, that the conscientious naval officer was too professionally oriented to be concerned with family. He wasn't. Remey appears to have maintained a healthy balance between family and naval obligations.

Molly Mason Remey's outlook throughout life was conventional. She was no pathfinder, no dreamer of great dreams beyond those involving her family, certainly not to the point that she felt compelled to "make a statement," to crusade, say, for women's rights. She did, when her children left home, do conventional good works, help the poor, and promote missions through her church. But child labor laws or woman suffrage, to name two possibilities, were apparently of no burning concern to her.

What Molly Remey was during her life was "good." One shouldn't read a late twentieth century cynicism into that word. She was a good child, a good daughter, a good wife, a good mother, and a good woman according to the mores of the nineteenth century. 
Copyright of Annals of Iowa is the property of State of Iowa, by \& through the State Historical Society of Iowa and its content may not be copied or emailed to multiple sites or posted to a listserv without the copyright holder's express written permission. However, users may print, download, or email articles for individual use. 